\title{
Minocycline Attenuates Neuronal Cell Death and Improves Cognitive Impairment in Alzheimer's Disease Models
}

\author{
Yoori Choi ', ${ }^{1,}$ Hye-Sun Kim 1,3, Ki Young Shin', Eun-Mee Kim', Minji Kim', Hyun-Soo Kim', \\ Cheol Hyoung Park', Yun Ha Jeong', Jongman Yoo', Jean-Pyo Lee', Keun-A Chang', Seonghan Kim' \\ and Yoo-Hun Suh*,
}

'Department of Pharmacology, College of Medicine, National Creative Research Initiative Center for Alzheimer's Dementia and Neuroscience Research Institute, MRC, Seoul National University, Seoul, South Korea; ${ }^{2}$ Department of Pediatrics, School of Medicine, University of California at San Diego, La Jolla, CA, USA

\begin{abstract}
Minocycline is a semi-synthetic tetracycline antibiotic that effectively crosses the blood-brain barrier. Minocycline has been reported to have significant neuroprotective effects in models of cerebral ischemia, traumatic brain injury, amyotrophic lateral sclerosis, and Huntington's and Parkinson's diseases. In this study, we demonstrate that minocycline has neuroprotective effects in in vitro and in vivo Alzheimer's disease models. Minocycline was found to attenuate the increases in the phosphorylation of double-stranded RNAdependent serine/threonine protein kinase, eukaryotic translation initiation factor-2 $\alpha$ and caspase 12 activation induced by amyloid $\beta$ peptide $1-42$ treatment in NGF-differentiated PC 12 cells. In addition, increases in the phosphorylation of eukaryotic translation initiation factor-2 $\alpha$ were attenuated by administration of minocycline in Tg2576 mice, which harbor mutated human APP695 gene including the Swedish double mutation and amyloid $\beta$ peptide ${ }_{1-42}$-infused rats. We found that minocycline administration attenuated deficits in learning and memory in amyloid $\beta$ peptide ${ }_{1-42}$-infused rats. Increased phosphorylated state of eukaryotic translation initiation factor-2 $\alpha$ is observed in Alzheimer's disease patients' brains and may result in impairment of cognitive functions in Alzheimer's disease patients by decreasing the efficacy of de novo protein synthesis required for synaptic plasticity. On the basis of these results, minocycline may prove to be a good candidate as an effective therapeutic agent for Alzheimer's disease.

Neuropsychopharmacology (2007) 32, 2393-2404; doi:I0.1038/sj.npp. I301377; published online 4 April 2007
\end{abstract}

Keywords: minocycline; alzheimer's disease; amyloid $\beta$ peptide; PKR; eukaryotic translation initiation factor-2 $\alpha$; Tg2576 mice

\section{INTRODUCTION}

Minocycline is a second-generation tetracycline that effectively crosses the blood-brain barrier (Yong et al, 2004). In addition to its antibiotic properties, minocycline has been reported to have neuroprotective effects in various experimental models of cerebral ischemia (Yrjanheikki et al, 1999), traumatic brain injury (Sanchez Mejia et al, 2001), amyotrophic lateral sclerosis (ALS) (Zhu et al, 2002), Parkinson's diseases (PD) (Wu et al, 2002), kainic acid treatment (Heo et al, 2006), Huntington's disease (HD) (Chen et al, 2000; Wang et al, 2003), and multiple sclerosis (Popovic et al, 2002). Additionally, minocycline was reported to attenuate white matter damage in a rat model of chronic cerebral hypoperfusion (Cho et al, 2006).

\footnotetext{
* Correspondence: Professor Y-H Suh, Department of Pharmacology, College of Medicine, National Creative Research Initiative Center for Alzheimer's Dementia and Neuroscience Research Institute, MRC, Seoul National University, Seoul, I I0-799, South Korea, Tel: + 822 740 8285, Fax: + 822745 7996, E-mail: yhsuh@snu.ac.kr

${ }^{3}$ These authors have equally contributed to this work. Received II September 2006; revised 22 January 2007; accepted 23 January 2007
}

Minocycline exerts its neuroprotective effects via mitochondrial permeability-transition mediated cytochrome $c$ release from mitochondria in ALS mice model (Zhu et al, 2002), the inhibition of caspase- 1 and -3 expressions in a HD transgenic mouse model (Wang et al, 2003), and the suppression of hypoxic activation of rodent microglia (Suk, 2004).

Recently, it has been reported that minocycline treatment suppressed microglial production of IL-1beta, IL-6, TNF, and NGF in in vitro as well as amyloid precursor protein (APP) transgenic mice, but did not affect amyloid beta peptide $(\mathrm{A} \beta)$ deposition in this Alzheimer's disease (AD) animal model (Seabrook et al, 2006).

$\mathrm{AD}$ is one of the most popular neurodegenerative disorders characterized neuropathologically by the presence of neuritic plaques composed of amyloid fibrils and neurofibrillary tangles, which primarily contain paired helical filaments of hyperphosphorylated tau (Selkoe, 2001). Although many lines of evidence have confirmed the finding that $\mathrm{A} \beta$ exhibits neurotoxicity and induces apoptosis, another hypothesis has emerged to show that synaptic failure and impairment of cognitive function occur in the early phase of $\mathrm{AD}$ before the appearance of neuronal degeneration (Selkoe, 2002). In fact, it has been demon- 
strated that oligomeric assemblies of $\mathrm{A} \beta$, observed during the growth of amyloid fibrils, can affect synaptic function including synaptic plasticity and cognitive function in vivo (Cleary et al, 2005; Walsh et al, 2002). As synaptic plasticity underlies cognitive function, such as learning and memory, its disruption would be expected to cause a decline of cognitive ability observed in AD.

It has been recently reported that mice lacking GCN2, one of the four kinases known to be responsible for the phosphorylation of eukaryotic initiation translation factor 2 alpha (eIF- $\alpha$ ), that is double-stranded RNA-dependent serine/threonine protein kinase (PKR), PKR-like endoplasmic reticulum kinase (PERK), heme-regulated eIF2 $\alpha$ kinase (HRI), exhibited enhanced long-term potentiation and sustained memory was induced when exposed to weak stimuli and training (Costa-Mattioli et al, 2005). Studies on a variety of different forms of synaptic plasticity have suggested a link between messenger RNA translation and learning and memory (Kandel, 2001). Phosphorylated eIF2 $\alpha$ (p-eIF $2 \alpha$ ) reduces general protein synthesis, but facilitates the mRNA translation of the transcriptional modulator ATF4 (Harding et al, 2000), which inhibits synaptic plasticity and behavioral learning by repressing CREB activity (Chen et al, 2003).

Stress conditions such as ultraviolet, endoplasmic reticulum (ER) stress, and reactive oxygen species (ROS) elicit a cellular adaptive response for the coordinated expression of stress-responding genes. One of these responses is the phosphorylation of eIF2 $\alpha$ (Harding et al, 1999).

Prolonged ER stress is linked to the pathogenesis of several neurodegenerative disorders, which include cerebral ischemia, PD, and AD (DeGracia and Montie, 2004; Katayama et al, 2004; Smith et al, 2005).

In this study, we demonstrate that minocycline exerts neuroprotective actions in in vitro and in vivo model of AD. Moreover, minocycline attenuated the phosphorylation of eIF- $2 \alpha$ induced by $\mathrm{A} \beta_{1-42}$ treatment or the expression of Cterminal fragments of APP (APP-CTs) in neuronal cells. We also found that minocycline improves the learning and memory impairments in the $\mathrm{A} \beta_{1-42}$-infused $\mathrm{AD}$ rat model (Nitta et al, 1997). The increases in p-eIF2 $\alpha$ were also attenuated by administration of minocycline in $\mathrm{Tg} 2576$ mice, which harbor mutated human APP695 gene including the Swedish double mutation as well as $\mathrm{A} \beta_{1-42}$-infused rats. These results suggest that minocycline could be a potential therapeutic agent for $\mathrm{AD}$.

\section{MATERIALS AND METHODS}

\section{Reagents and Antibodies}

Minocycline was obtained from Sigma (MO, USA). A $\beta_{1-42}$, from US Peptide (CA, USA). Anti-caspase-12, anti-phospho-eIF-2 $\alpha$, anti-p-PKR antibodies were obtained from Cell Signaling (MA, USA), and eIF2 $\alpha$ antibody was from Biosource (CA, USA).

\section{DNA Constructs}

The cDNA constructs of APP-C59 and APP-C99 were generated by PCR from human APP695 cDNA and encompassed the last 59 or 99 amino-acid residues, respectively. They were subcloned into a pcDNA3-flag vector with the flag at the $\mathrm{N}$ terminus. All constructs were sequenced using an ABI310 Sequencer.

\section{Cell Culture and Transfection}

PC12 cells were plated on polyethyleneimine (PEI, $0.2 \mathrm{mg} /$ ml; Sigma, MO, USA) coated plates and maintained in DMEM (Life Technologies Inc., Grand Island, NY, USA) supplemented with $10 \%$ FBS (GIBCO BRL, NY, USA) and $0.3 \%$ antibiotics at $37^{\circ} \mathrm{C}$ in $5 \% \mathrm{CO}_{2} . \mathrm{PC} 12$ cells were treated with nerve growth factor (NGF, $50 \mathrm{ng} / \mathrm{ml}$ ) from Invitrogen (CA, USA) and allowed to differentiate for 4 days. NGF differentiated PC12 cells were transiently transfected with $2 \mu \mathrm{g}$ of plasmid DNA and $3 \mu \mathrm{l}$ of Fugene 6 (Roche Molecular Biochemicals, Germany) in $1 \mathrm{ml}$ of growing medium according to the manufacturer's instructions.

\section{Cell Viability Assay}

MTT-metabolizing activity was determined at $48 \mathrm{~h}$ posttransfection according to the manufacturer's instructions (Sigma). LDH activities in the conditioned media were measured using a Cytotox96 nonradioactive cytotoxicity assay kit (Promega, WI, USA) according to the manufacturer's instructions. The percentage of $\mathrm{LDH}$ release was obtained by comparing to the maximal release of positive control treated with $1 \%$ Triton-X 100.

\section{Western Blotting}

Protein was resolved in SDS polyacrylamide gel, electrophoresed at 30-50 $\mu \mathrm{g}$ of protein/lane, and transferred onto a nitrocellulose membrane (Amersham Pharmacia, Buckinghamshire, UK). The protein blot was confirmed with appropriate antibodies and detected using horseradish peroxidase-conjugated secondary antibody (Amersham Pharmacia). Immunoreactive bands were visualized using an enhanced chemiluminescence system (ECL; Amersham Pharmacia).

\section{Subcellular Fractionation for Microsomes}

Cells were resuspended in hypotonic buffer A $(250 \mathrm{mM}$ sucrose, $20 \mathrm{mM}$ Hepes, $\mathrm{pH} 7.5,10 \mathrm{mM} \mathrm{KCl}, 1.5 \mathrm{mM} \mathrm{MgCl}_{2}$, $1 \mathrm{mM}$ EDTA, $1 \mathrm{mM}$ EGTA, protease inhibitor) on ice for $30 \mathrm{~min}$. Cells were disrupted by passing through 26-gauge needle 30 times, and then 30-gauge needle 20 times. Cell lysates were centrifuged at $750 \mathrm{~g}$ for $10 \mathrm{~min}$ at $4^{\circ} \mathrm{C}$. The supernatant was centrifuged at $10000 \mathrm{~g}$ for $20 \mathrm{~min}$ at $4^{\circ} \mathrm{C}$, the pellet as the mitochondrial fraction. The supernatant was centrifuged at $100000 \mathrm{~g}$ for $1 \mathrm{~h}$ at $4^{\circ} \mathrm{C}$. The pellet was saved as cytosolic fraction and the pellet as the microsome (ER enrichment). The purity of the fractions was checked with subcellular markers, that is calnexin for ER, $\beta$-actin for cytosol, and cytochrome $c$ oxidase IV for checking mitochondrial contamination.

\section{$A \beta_{1-42}$ Infused AD Rat Model}

Male Wistar rats weighing 200-250g (7-week-old) were housed in a specific pathogen-free room that was auto- 
matically maintained on a 12 -h light/dark cycle at $25^{\circ} \mathrm{C}$ and proper humidity. Animals were handled in accordance with 'the Guidelines for Animal Experiments of Ethics Committee of Seoul National University'. They had free access to food and water. The $\mathrm{A} \beta_{1-42}$ peptides were dissolved in $35 \%$ acetonitrile $/ 0.1 \%$ trifluoroacetic acid. The rats were anesthetized with sodium pentobarbital $(40 \mathrm{mg} / \mathrm{kg}$, i.p.). Continuous infusion of $\mathrm{A} \beta_{1-42} \quad(600 \mathrm{pmol} / \mathrm{day})$ was maintained for a week by attachment of an infusion kit connected to an osmotic mini-pump (Alzet 1007D; Alza, CA, USA). Sham-operated rats were infused with $35 \%$ acetonitrile $/ 0.1 \%$ trifluoroacetic acid. The infusion kit was implanted into the right ventricle $(1.2 \mathrm{~mm}$ posterior to the berema, $1.5 \mathrm{~mm}$ lateral to the midline, $4.0 \mathrm{~mm}$ ventral to the surface of the skull, according to the brain atlas of Paxinos and Watson. Minocycline $(45 \mathrm{mg} / \mathrm{kg} /$ day) or PBS was then injected i.p. for 3 weeks.

\section{Transgenic Mice}

Tg2576 mice harboring the mutated human APP695 gene were obtained from Taconic (German Town, NY, USA). The production, genotyping, and background strain (C57BL/ $6 \times$ SJL) of Tg2576 mice used in this study were described previously (Hsiao et al, 1996). All experiments were performed in accordance with 'the Guidelines for Animal Experiments from the Ethics Committee at Seoul National University'. Minocycline $(10 \mathrm{mg} / \mathrm{kg} /$ day $)$ or PBS was administered to Tg2576 mice or wt mice i.p. from 3 months after birth, 5 days per week for 9 months.

\section{Morris Water-Maze Task}

The experimental apparatus, which is a circular water tank ( $140 \mathrm{~cm}$ in diameter, $45 \mathrm{~cm}$ high) was filled with opaque water made by adding dry milk powder to water at the temperature of $21-23^{\circ} \mathrm{C}$ and located in a laboratory that contained prominent extra-maze cues. Animals are required to find a submerged platform $(15 \mathrm{~cm}$ in diameter, $35 \mathrm{~cm}$ high) in the pool using the spatial cues. The two starting points were changed daily. Spatial training consisted of five sessions, (two trials per session per day) during which the platform was left in the same position. In each training session, the latency to escape on to the hidden platform was recorded. After final train session, a single probe trial was conducted. The escape platform was removed, and each rat was allowed to swim for $90 \mathrm{~s}$ in the maze. The number of times the rat crossed the annulus where the platform had been located was recorded. Data collection was automated by a video image motion analyzer (Ethovision, Noldus Information Technology h.v., Netherlands).

\section{Passive Avoidance Test}

Wistar rats were handled for 3 days before the start of the behavioral experiments. The apparatus and experimental procedure used in the passive avoidance test comprised of a two-compartment step-through passive avoidance apparatus made of black Perspex was used. The apparatus consisted of illuminated and dark compartments $(25 \times 25 \times 25 \mathrm{~cm})$ attached to a grid floor and were separated by a guillotine door. The rat was placed in the illuminated compartment and the door was raised. After entering the dark compartment, the rat was returned to its home cage. After further $30 \mathrm{~min}$, the rat was again placed in the illuminated compartment. When the rat entered the dark compartment, the guillotine door was closed. Scrambled electrical foot shocks with intensity of $0.5 \mathrm{~mA}$ were delivered for $3 \mathrm{~s}$ through the grid floor using a shock generator. In the test trial made $24 \mathrm{~h}$ after the second trial, the rat was placed again in the illuminated compartment and the response latency to enter the dark compartment was measured up to a maximum of $300 \mathrm{~s}$.

\section{Human AD Brains}

Paraffin-embedded brain stocks of $\mathrm{AD}$ and age-matched control subjects were obtained from the Netherlands Brain Bank (NBB). Coronal sections $(4 \mu \mathrm{m})$ were cut through the hippocampus and processed for immunohistofluorescence. All experimental procedures were performed in accordance with 'the Guidelines of the Ethics Committee at Seoul National University'.

\section{Immunohistochemistry}

Fixed wild-type, Tg2576 mice brains, human AD or agematched control human brains in $10 \%$ neutral buffered formalin for $48 \mathrm{~h}$ were dehydrated and embedded in paraffin. Before immunostaining, slides were deparaffinized by oven heating and immersion in xylene. After dehydration through graded alcohols to water, a primary antibody was revealed by incubating the cells for $45 \mathrm{~min}$ with $\mathrm{Cy}^{\mathrm{TM}}$ 3-conjugated secondary antibody (Molecular Probes, Carlsbad, CA). After three washes with permeabilization buffer and one wash with PBS, cells were mounted on microscope slides in mounting medium (DAKO, CA). Confocal microscopic observation was performed using Zeiss LSM510 (Jena, Germany).

\section{Hematoxylin-Eosin (H\&E) Staining}

The rats were anesthetized with $10 \%$ chloral hydrate $(350 \mathrm{mg} / \mathrm{kg})$, i.p. Then the rats were perfused with $200 \mathrm{ml}$ $0.9 \% \mathrm{NaCl}$ solution and subsequently with $4 \%$ paraformaldehyde in $0.1 \mathrm{~mol} / \mathrm{l}$ phosphate buffer at $\mathrm{pH}$ 7.4. Brains were removed and post-fixed for $24 \mathrm{~h}$ in the same fixative. The post-fixed brains were cryo-protected in $25 \%$ sucrose in PBS. Then the brains were removed, paraffin-embedded, and coronally sectioned at $7 \mu \mathrm{m}$ thickness. The sections were then mounted on slides and stained with H\&E. The cell loss of the hippocampal area was assessed and quantified under a microscope. Neuronal damage was expressed as a percentage of the number of eosinophilic cells/the total number of cells in each region in the hippocampal area.

\section{Statistical Analysis}

Data are expressed as mean \pm SEM values. One-way ANOVA test was used for statistical significance, where $P<0.05$ was considered to be significant. 


\section{RESULTS}

\section{Transient Transfection into Nerve Growth Factor-} Differentiated PC 12 Cells

In this study, we investigated the effects of minocycline on APP-C59 or APP-C99-induced cytotoxicities, p-eIF2 $\alpha$, and caspase 12 in differentiated PC 12 cells employing a transient transfection system. Under our experimental conditions, transient transfection efficiencies using Fugene 6 reagent were assessed with GFP vector in differentiated PC 12 cells. The transfection efficiency was $40.0 \pm 4.0 \%$ $(n=5)$ in PC 12 cells, as confirmed by the expression of GFP fluorescence. In addition, we confirmed the expression of APP-C59 or APP-C99 by Western blotting after transfection (data not shown).

\section{Minocycline Inhibited the Increases in p-eIF2 $\alpha$ and Reduced the Neuronal Cell Death Induced by $\mathrm{A} \beta_{1-42}$ Treatment}

$\mathrm{A} \beta$ plays an important role in the pathogenesis of $\mathrm{AD}$ (Yankner, 1996). Initially, we tested whether minocycline affects the reduced viability of NGF-differentiated PC12 cells induced by $\mathrm{A} \beta_{1-42}$ treatment, using LDH release, and the MTT-reduction assay. We examined dose-dependent effects of minocycline over $\mathrm{A} \beta_{1-42}$ treatment $(30 \mu \mathrm{M}, 24 \mathrm{~h})$. The condition of $\mathrm{A} \beta_{1-42}$ treatment at $30 \mu \mathrm{M}$ for $24 \mathrm{~h}$ was chosen based on our preliminary study (data not shown) and study by others (Schuster et al, 2005), in which $25 \mu \mathrm{M}$ concentration of $\mathrm{A} \beta_{1-42}$ reduced cell viability by about $20 \%$. Minocycline at concentrations of $1,5,10,20 \mu \mathrm{M}$ minocycline were pretreated in differentiated PC 12 cells $24 \mathrm{~h}$ before $\mathrm{A} \beta_{1-42}$ treatment. Minocycline significantly inhibited LDH release by $\mathrm{A} \beta_{1-42}$, dose-dependently from 0,1 to $5 \mu \mathrm{M}$, however, there its effect reached plateau at $5 \mu \mathrm{M}$ (Figure $1 \mathrm{~b}$ ). Based on the results by us and by others (Suk, 2004; Wang et al, 2003; Zhu et al, 2002), $10 \mu \mathrm{M}$ concentration of minocycline was chosen for this study.

We found that pretreatment with minocycline at $10 \mu \mathrm{M}$ for $24 \mathrm{~h}$ significantly attenuated $\mathrm{A} \beta_{1-42}$-induced $\mathrm{LDH}$ release $(30 \mu \mathrm{M}$ for $24 \mathrm{~h})$, from $14.03 \pm 4.21 \%$ to $4.91 \pm 0.70 \%$ in NGF-differentiated PC 12 cells (Figure 1a). For the MTT assay, minocycline restored the decrease in MTT reduction by $\mathrm{A} \beta_{1-42}$ from $86.02 \pm 4.30 \%$ to $96.77 \pm 1.07 \%$.

It has been reported that the phosphorylated form of eIF $2 \alpha$ and activation of PKR are increased in the degenerating neurons of the brains from $A D$ patients (Chang et al, 2002a) and in cultured neuronal cells treated with $\mathrm{A} \beta$ (Chang et al, 2002b). Here, we checked whether minocycline affects the upregulated p-eIF- $2 \alpha$ induced by $\mathrm{A} \beta_{1-42}$ treatment, and found that minocycline attenuated the increases in p-eIF- $2 \alpha$ at serine 51 by $\mathrm{A} \beta_{1-42}$ treatment in minocycline pretreated NGF-differentiated PC 12 cells by about $20 \%$, whereas eIF $2 \alpha$ was not affected by $\mathrm{A} \beta_{1-42}$ or by minocycline (Figure 1c). A $\beta$ is reported to phosphorylate eIF- $2 \alpha$ via PKR activation in neuronal cells (Chang et al, 2002a; Suen et al, 2003). We investigated the effects of minocycline on PKR phosphorylation caused by $\mathrm{A} \beta_{1-42}$. $\mathrm{A} \beta_{1-42}$ treatment increased p-PKR by about $25 \%$ and minocycline pretreatment reverted phosphorylation at threonine 446 and 451 (Figure 1d) to the control level, but did not affect PKR (data not shown). In response to ER stress caused by various stimuli such as intracellular calcium homeostasis perturbation, ROS, and protein misfolding, eIF $2 \alpha$ becomes phosphorylated (Lindholm et al, 2006). Results from Western blots showed that minocycline attenuated activation of caspase 12 induced by $\mathrm{A} \beta_{1-42}$ treatment (Figure 1e).

\section{Minocycline Reduced the Upregulation of p-eIF2 $\alpha$ and Attenuated Neuronal Cell Death Induced by the C-terminal Fragments of Amyloid Precursor Protein}

Next, we examined the effects of minocycline on the cell death induced by the expression of the APP-CTs in NGFdifferentiated PC12 cells. Treatment with minocycline at $10 \mu \mathrm{M}$ for $48 \mathrm{~h}$ post-transfection significantly reduced cytotoxicity induced by APP-C59 from $23.18 \pm 1.18$ to $6.36 \pm 1.82 \%$ (Figure 2a). For APP-C99 transfection, LDH release was reduced from $29.09 \pm 1.90 \%$ to $6.82 \pm 1.80 \%$ (Figure 2a). The MTT reduction assay showed that minocycline pretreatment significantly ameliorated the decrease in MTT reduction by APP-C59 from 75.00 \pm 2.08 to $91.67 \pm 2.08 \%$ and that of APP-C99 from $68.75 \pm 2.08$ to $91.80 \pm 1.51 \%$ (Figure 2a). In addition, we found that increases in p-eIF- $2 \alpha$ induced by APP-CTs expression were significantly attenuated by minocycline pretreatment in NGF-differentiated PC12 cells by about 20\% (APP-C59) and $44 \%$ (APP-C99), whereas eIF2 $\alpha$ was unaffected by either $\mathrm{A} \beta_{1-42}$ or by minocycline (Figure $2 \mathrm{~b}$ ). Figure $2 \mathrm{~b}$ shows that p-eIF $2 \alpha$ in the mock control group was slightly reduced by minocycline even though there was no significant difference. This discrepancy remains to be elucidated by further study.

\section{Minocycline Reduced Neuronal Death and Attenuated Learning and Memory Impairment in an $A \beta_{1-42}$ Infused AD Rat Model}

Here we assessed the effects of minocycline in in vivo $\mathrm{AD}$ model. $\mathrm{A} \beta_{1-42}$ (600 pmole/day) or the vehicle ( $35 \%$ acetonitrile/0.1\% trifluoroacetic acid) was infused into lateral ventricles of male Wistar rats weighing 200-250 g (7-week old) continuously for a week. Minocycline $(45 \mathrm{mg} / \mathrm{kg} /$ day $)$ or PBS was then injected i.p. for 3 weeks into $\mathrm{A} \beta_{1-42}$ ( $600 \mathrm{pmol} /$ day)- or vehicle ( $35 \%$ acetonitrile/ $0.1 \%$ trifluoroacetic acid)-infused sham-operated groups. The minocycline concentration used in this study $(45 \mathrm{mg} / \mathrm{kg} /$ day, i.p.) was chosen, based on the report by others (Hunter et al, 2004a). Three weeks after completing the i.p. injections, we tested for spatial learning and memory impairment using Morris Water Maze test in the PBS- or minocycline-treated animals of $\mathrm{A} \beta_{1-42} \quad(600 \mathrm{pmol} /$ day $)$ or sham-operated groups. The $\mathrm{A} \beta_{1-42}$-infused minocycline-treated group showed shorter latency times than the PBS-injected group from the second day of these learning sessions (ANOVA, $P<0.05$, Figure $3 a$ ). We confirmed no noticeable differences between the sham-operated animals treated with PBS or minocycline (Figure $3 \mathrm{a}$ ). To confirm whether the memory impairment shown in the $\mathrm{A} \beta_{1-42}$ infused rats was actually attenuated by minocycline treatment, we performed the 

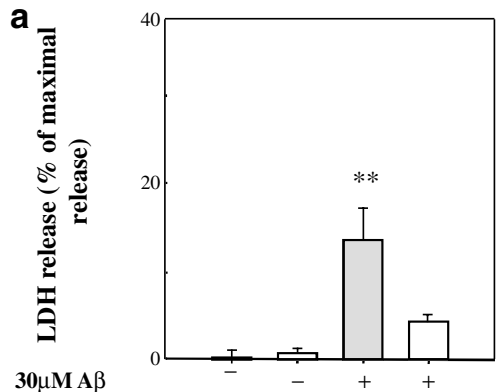

$10 \mu \mathrm{M}$ minocycline

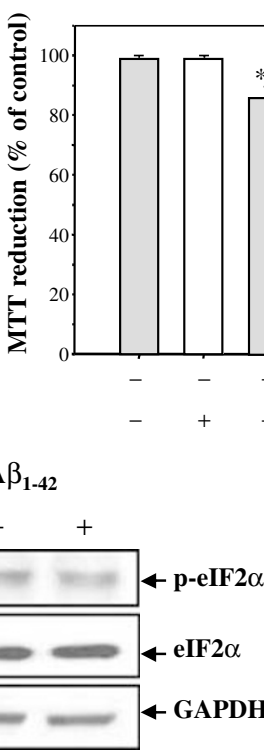

C b

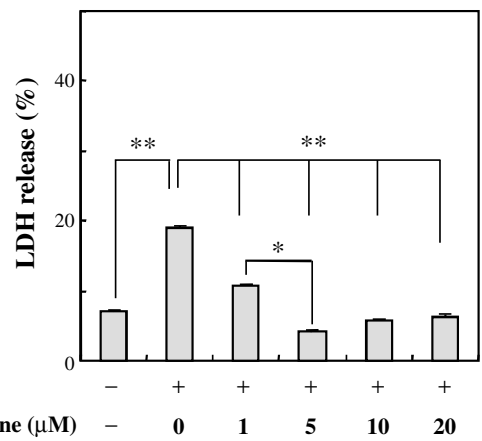

d
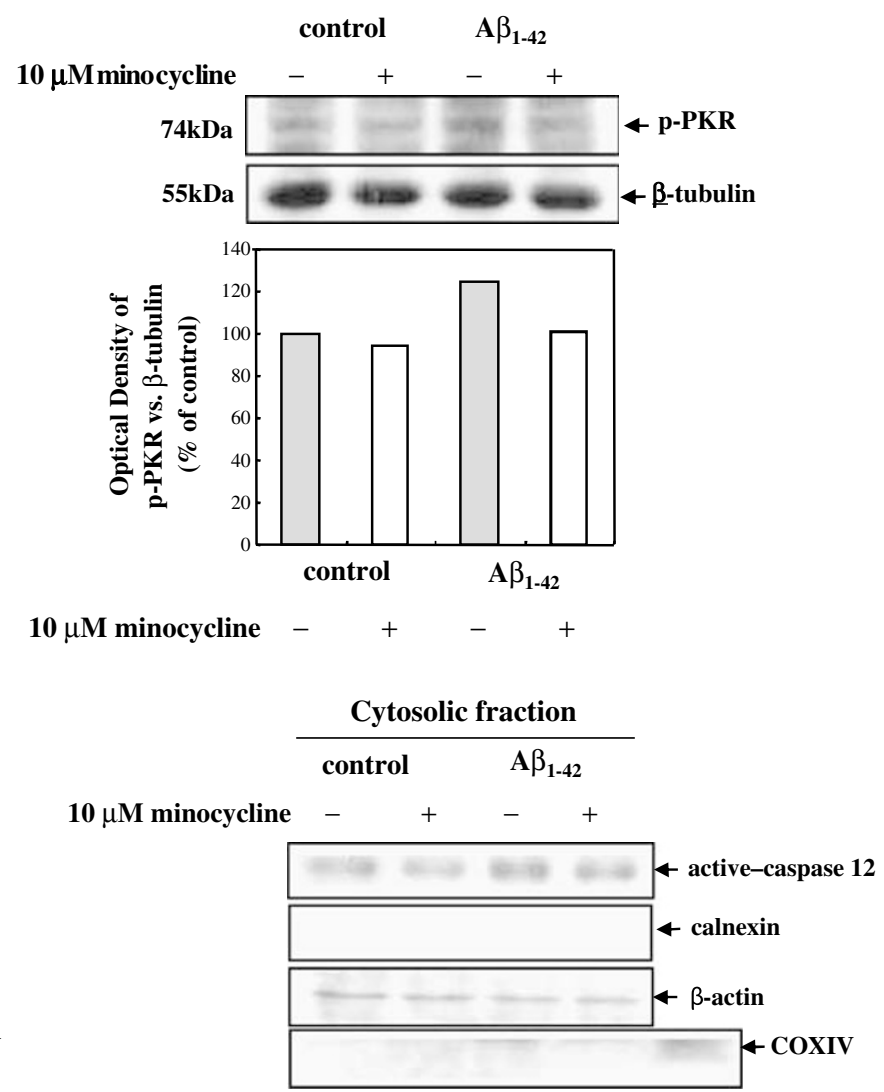

Figure I Minocycline inhibited the increases in p-elF2 $\alpha$ and reduced the neuronal cell death induced by $A \beta_{1-42}$ treatment. (a) Differentiated PCI2 cells were pretreated with vehicle (PBS) or $10 \mu \mathrm{M}$ minocycline for $24 \mathrm{~h}$ and then treated with $30 \mu \mathrm{M} A \beta_{1-42}$. Twenty four hours after $\mathrm{A} \beta_{1-42}$ treatment, cell viability was measured by LDH or MTT activity vs the control (vehicle-treated PCI 2 cells). Data represent mean \pm SEM obtained from I 6 culture wells per experiment, determined in four independent experiments. Asterisks indicate significantly different from the PBS-pretreated $30 \mu \mathrm{M} A \beta_{1-42}$ treated group $(* * P<0.01$ by one-way ANOVA). The percentage of $\mathrm{LDH}$ release was obtained by comparing to the maximal release of positive control treated with $1 \%$ Triton-X 100. (b) Dose-dependent effects of minocycline over $A \beta_{1-42}$ treatment $(30 \mu \mathrm{M}, 24 \mathrm{~h})$ were examined. $0,1,5,10,20 \mu \mathrm{M}$ concentrations of minocycline was pretreated for $24 \mathrm{~h}$ and then treated with $30 \mu \mathrm{MA} \beta_{\perp-42}$. Twenty-four hours after $\mathrm{A} \beta_{\perp-42}$ treatment, cell viability was measured by LDH vs the control (vehicle-treated PCI 2 cells). Data represent mean \pm SEM obtained from 10 culture wells per experiment, determined in two independent. (c) Differentiated $\mathrm{PCl} 2$ cells were pretreated with vehicle or $10 \mu \mathrm{M}$ minocycline and then treated with $30 \mu \mathrm{M} A \beta_{1-42}$ for $24 \mathrm{~h}$. P-elF-2 $\alpha$ and elF2 $\alpha$ levels were checked by immunoblotting whole cell lysates. GAPDH was used as a loading control. Densitometric analysis was also carried out, and results are presented as means \pm SEM of three independent experiments (**P $<0.01$, $* P<0.05$ by one-way ANOVA). (d) Differentiated $P C I 2$ cells were pretreated with vehicle or $10 \mu \mathrm{M}$ minocycline and then treated with $30 \mu \mathrm{MA} \beta_{1-42}$ for $24 \mathrm{~h}$. P-PKR levels were checked by immunoblotting using whole cell lysates. $\beta$-Tubulin was used as a loading control. Relative ratio of the densitometric values of p-elF2 $\alpha$ and elF2 $\alpha$ is normalized using the M4 image analysis program. (e) Changes in procaspase 12 levels in ER-enriched fractions and of activated caspase 12 in the cytosolic fraction were detected by immunoblotting with anti-caspase 12 antibody. The purity of the fractions was checked with subcellular markers, that is calnexin for ER, $\beta$-actin for cytosol, and cytochrome $\mathrm{c}$ oxidase IV for checking mitochondrial contamination.

probe test, and recorded the average latency during the stay at the zone 1 without platform. Minocycline-treated rats stayed significantly longer in zone 1 than at the other zones (zones 2-4) (ANOVA, $P<0.05$, Figure $3 \mathrm{~b}$ ). However, no significant differences were observed for PBS-treated animals in terms of times spent in different zones 
(Figure 3b). There was no noticeable differences in the sham-operated animals treated with $\mathrm{PBS}$ or minocycline (Figure $3 b$ ).

To determine whether minocycline affects short- and long-term working memory impairment induced by $\mathrm{A} \beta_{1-42}$ infusion, we performed passive avoidance testing. The minocycline-treated group showed significantly longer latencies than the PBS treated $\mathrm{A} \beta_{1-42}$ infused rats (oneway ANOVA, $P<0.05$, Figure $3 \mathrm{c}$ ). There was no noticeable difference between the sham-operated animals treated with the vehicle (PBS) or minocycline (Figure 3c). Next, we checked neuronal cell death by $\mathrm{H} \& \mathrm{E}$ staining in the $\mathrm{A} \beta_{1-42}$ infused rat model, and found that minocycline treatment significantly reduced neuronal cell death in the hippocam- pus and dentate gyrus in an $\mathrm{A} \beta_{1-42}$ infused rat model (Figure 3d). The percentage of eosinophilic cells $v s$ total cells in dentate gyrus was $7.75 \pm 1.98 \%$ for the PBS-treated, and $10.38 \pm 2.4 \%$ in minocycline-administered sham-operated rats and $52.38 \pm 7.25 \%$ for the PBS-treated, and $12.70 \pm 2.43 \%$ in minocycline-administered $\mathrm{A} \beta_{1-42}$ infused rats, respectively. In CA3, the percentage of eosinophilic cells $v s$ total cells was $17.88 \pm 2.79 \%$ for the PBS-treated, and $19.02 \pm 3.62 \%$ in minocycline-administered sham-operated rats and $67.48 \pm 6.72 \%$ for the PBS and $32.30 \pm 4.40 \%$ in minocycline-administered $\mathrm{A} \beta_{1-42}$ infused rats, respectively (Figure 3e). All in vivo experiments were performed in accordance with 'the Guidelines for Animal Experiments of Ethics Committee of Seoul National University'. a

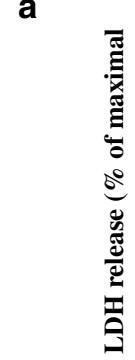

Transfection

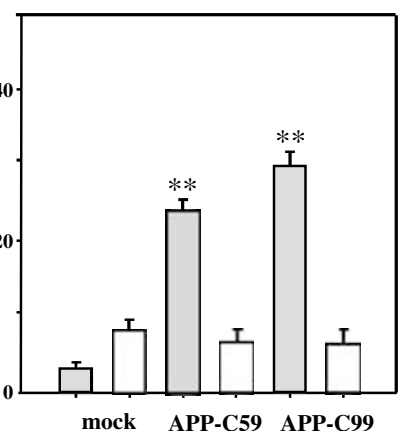

mock APP-C59 APP-C99

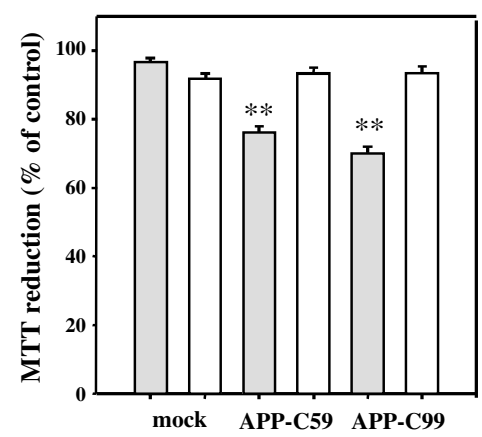

b
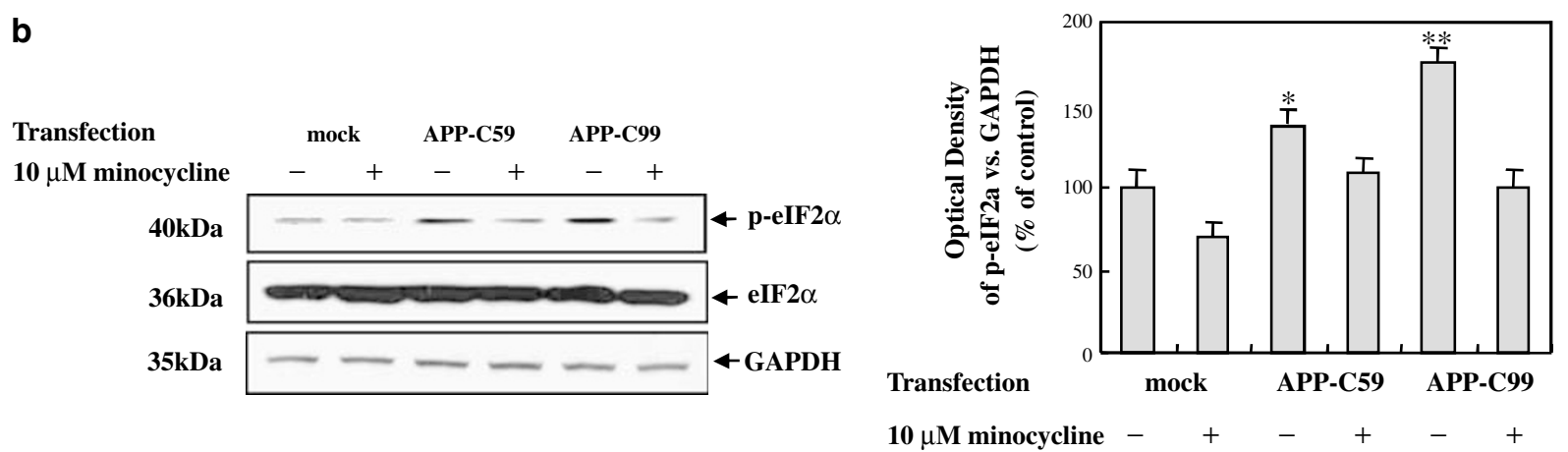

Figure 2 Minocycline reduced the upregulation of $\mathrm{p}$-elF2 $\alpha$ and attenuated the neuronal cell death induced by the C-terminal fragments of amyloid precursor protein. (a) NGF-differentiated PCI 2 cells were transfected with mock, APP-C59, or APP-C99, and then treated with vehicle (PBS) or I0 $\mu$ M minocycline $6 \mathrm{~h}$ post-transfection. After $48 \mathrm{~h}$, cell viabilities were determined by LDH release and MTT assays. Results are expressed as percentages of peak $\mathrm{LDH}$ or MTT activities in the control (non-transfected PCI 2 cells). Data represent mean \pm SEM obtained from 16 culture wells per experiment, determined in four independent experiments. The percentage of $\mathrm{LDH}$ release was obtained by comparing to the maximal release of positive control treated with $1 \%$ Triton-X 100. Asterisks indicate significantly different from PBS-treated mock-transfected cells $(* P<0.01$ by one-way ANOVA). (b) PCI2 cells were transfected with mock, C59, or C99 and then treated with vehicle or $10 \mu \mathrm{M}$ minocycline $6 \mathrm{~h}$ post-transfection. After $48 \mathrm{~h}$, levels of p-elF $2 \alpha$ and elF2 $\alpha$ were examined by immunoblotting. GAPDH was used as a loading control. Densitometric analysis was also performed. The results are presented as means \pm SEM of three independent experiments (**P $<0.01$, *P $<0.05$ by one-way ANOVA ).

Figure 3 Minocycline reduced neuronal death and attenuated learning and memory impairment in an $A \beta_{1-42}$ infused $A D$ rat model. (a) $A \beta_{1-42}$ (600 pmol/day) dissolved in 35\% acetonitrile/0.1\% trifluoroacetic acid was infused into lateral ventricles using an osmotic pump for 7 days. Sham-operated rats were infused with $35 \%$ acetonitrile $/ 0.1 \%$ trifluoroacetic acid only. Minocycline $(45 \mathrm{mg} / \mathrm{kg} / \mathrm{day})$ or PBS was administered intraperitoneally during the following 3 weeks into sham-operated or $A \beta_{1-42}$ infused rats. After the water maze test training, testing was performed over five sessions after minocycline or vehicle had been administered. Latency times for the animals in the minocycline-treated group were compared to those of PBS-treated animals (one-way ANOVA, $P<0.05$ vs vehicle). (b) The probe test was performed after the final training session. The times that rats of the minocycline injected group stayed in zones I, 2, 3, and 4 were compared to those of the vehicle injected group (one-way ANOVA, $P<0.05$ vs vehicle). (c) In the passive avoidance test, the latency times of PBS or minocycline-treated sham-operated or $A \beta_{1-42}$ infused rats were compared with each other (one-way ANOVA, *P $<0.05$, ** $P<0.01$ vs vehicle). (d) Hematoxylin and eosin-stained sections of the hippocampal areas (dentate gyrus, CA3) of PBS or minocycline administered group after vehicle (35\% acetonitrile/ $0.1 \%$ trifluoroacetic acid only) or $A \beta_{1-42}$ infusion were observed. Note that the depth of staining of neurons was reduced by minocycline pretreatment in $A \beta_{1-42}$ infused rats. (e) The percentage of eosinophilic cells vs total cells was calculated in dentate gyrus and CA3 of PBS or minocycline administered sham-operated or $A \beta_{1-42}$ infused rats (one-way ANOVA, $* P<0.05, * * P<0.01$ vs vehicle). 
The Increases in p-eIF $2 \alpha$ were Attenuated by Administration of Minocycline in $A \beta_{1-42}$ Infused Rats and in Tg2576 Mice

From the in vitro studies (Figures 1 and 2), p-eIF $2 \alpha$ increased by following $\mathrm{A} \beta_{1-42}$ treatment or transfection of APP-CTs. Here, we investigated whether the phosphoryla-

a

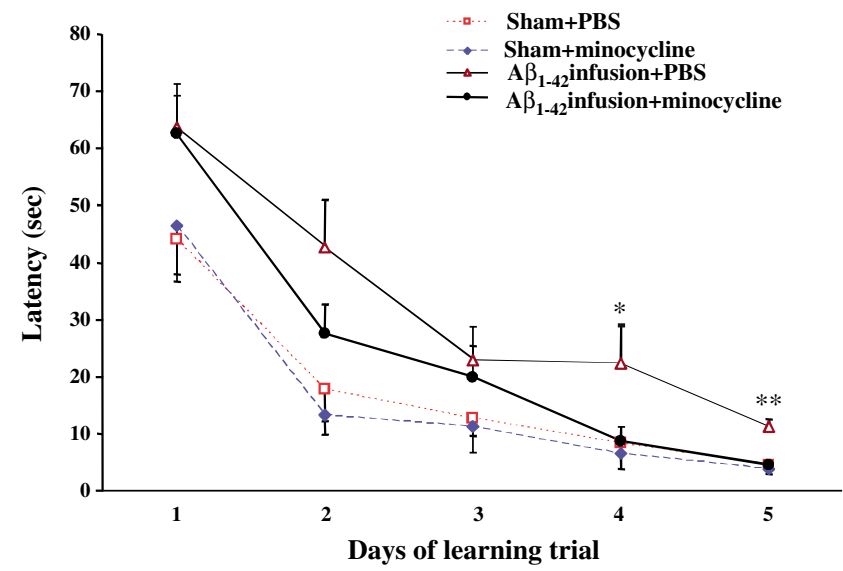

tion of eIF $2 \alpha$ was also altered in the brains of $A \beta_{1-42}$ infused rats compared to sham-operated control rats. To examine the in situ distribution of p-eIF $2 \alpha$, sections from the hippocampus of control and $\mathrm{A} \beta_{1-42}$ infused rats were stained with p-eIF $2 \alpha$-specific antibody. The immunoreactivities of p-eIF $2 \alpha$ in the CA1 and CA3 of hippocampus of $\mathrm{A} \beta_{1-42}$ infused rats were found to be increased significantly

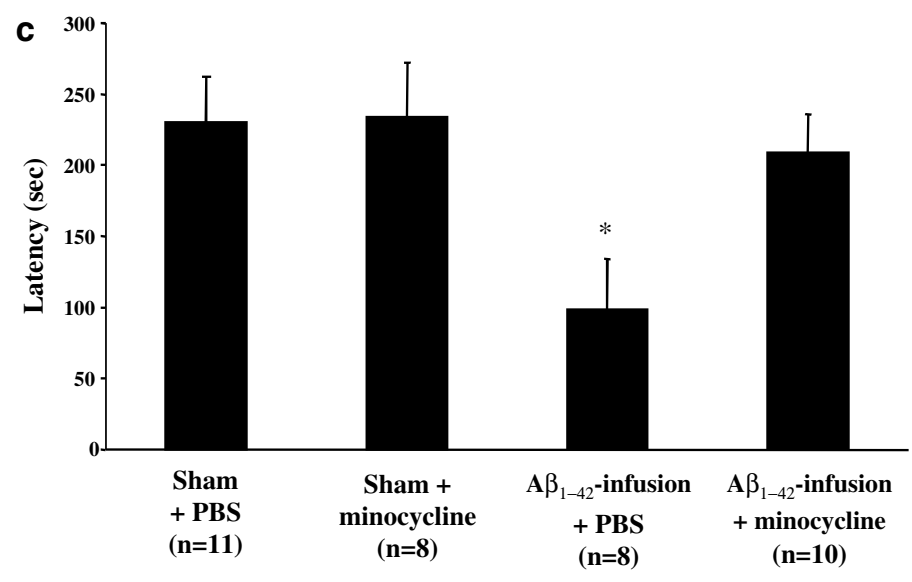

d

Sham+

PBS

Sham+

minocycline

A $\beta 1-42^{\text {infusion }}$ + PBS

A $\beta_{1-42}$ infusion + minocycline

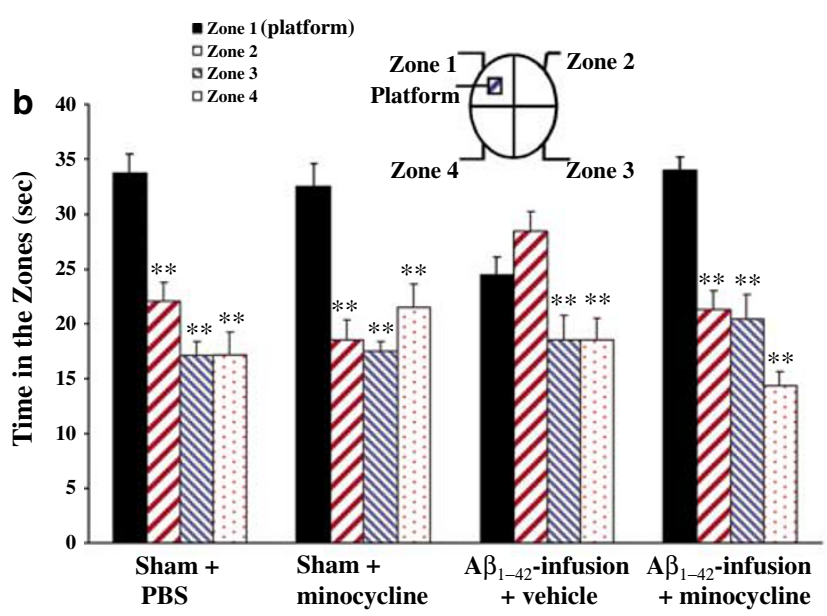

e

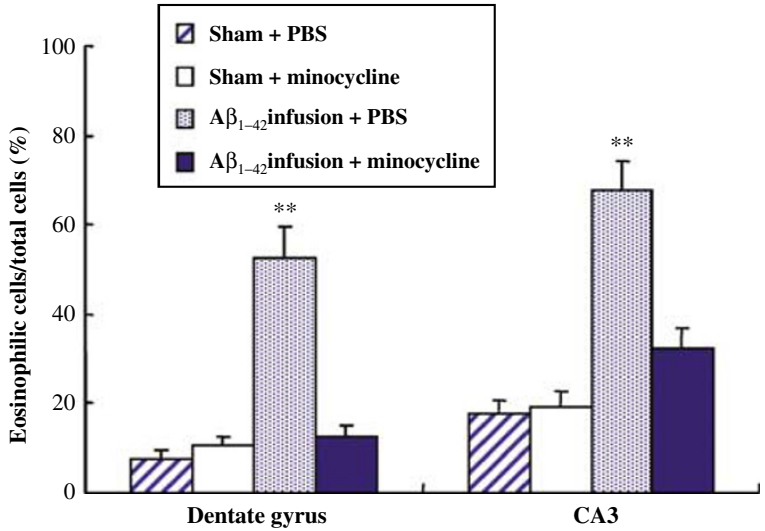


a

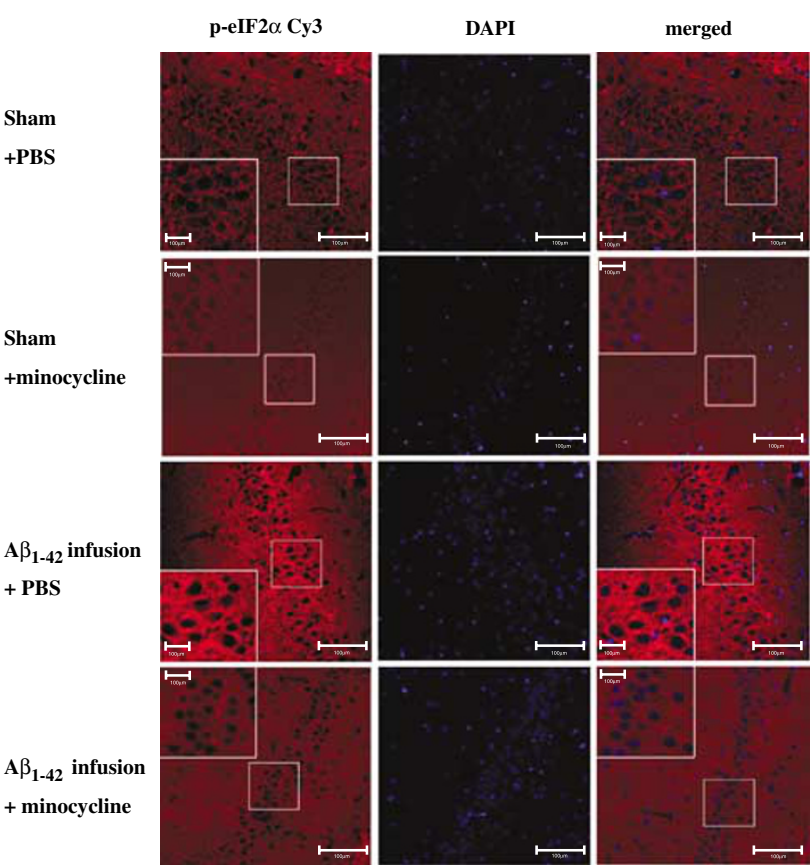

C

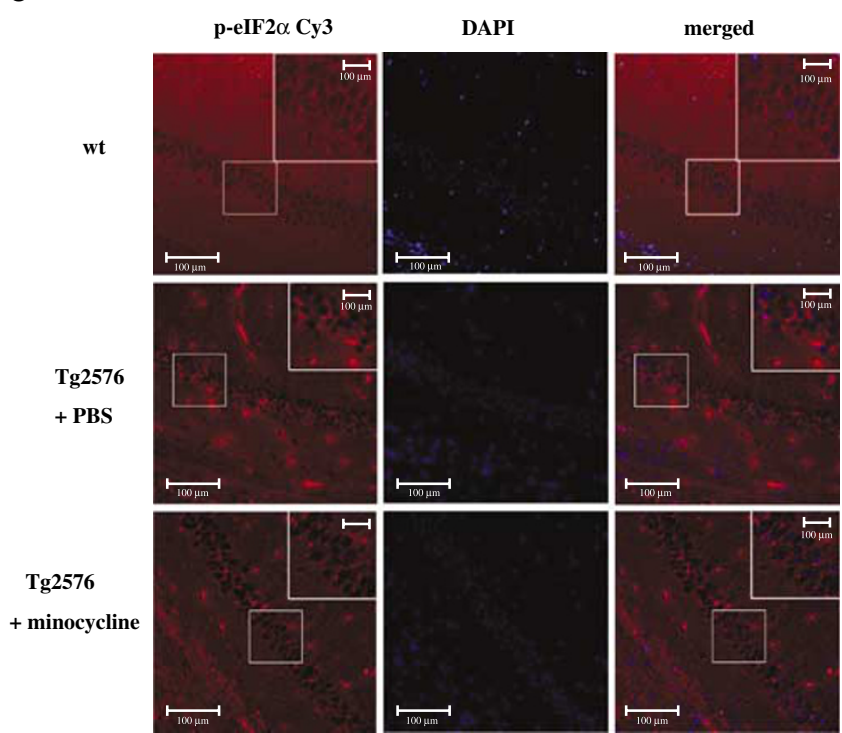

b

A $\beta_{1-42}$ infused rat brain - Hippocampus CA3

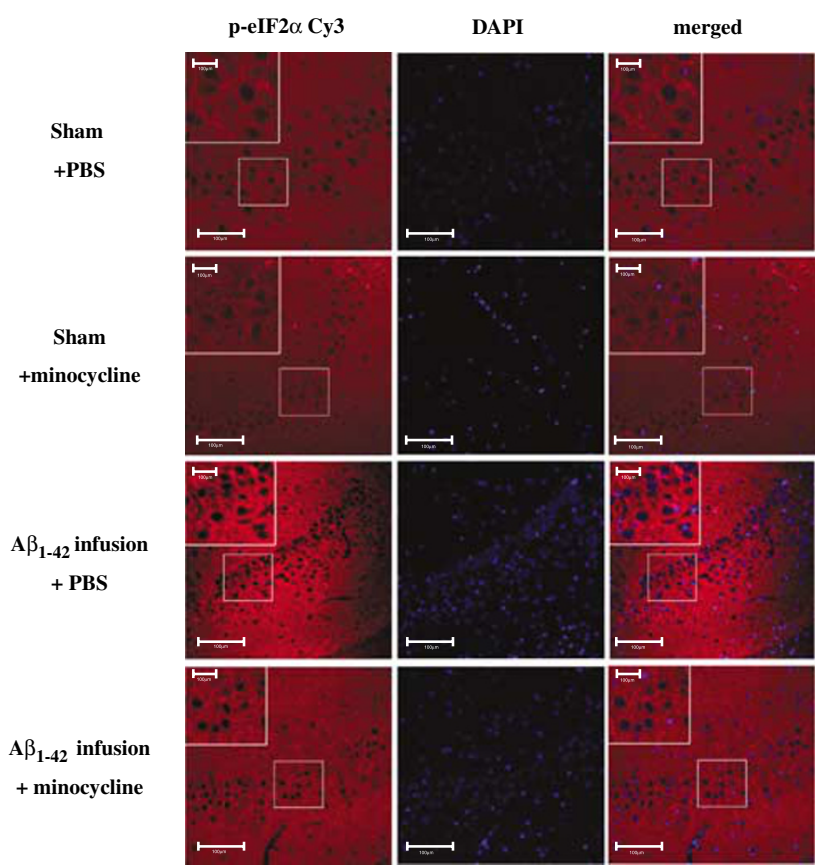

d

Tg2576 mouse - Hippocampus CA3 (x200)

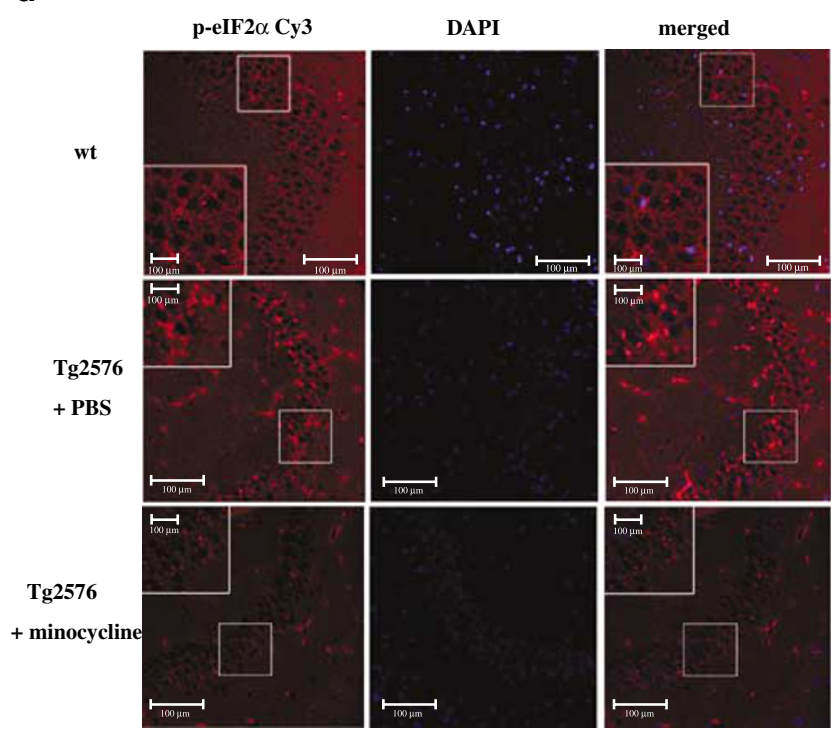

Figure 4 The increases in p-elF2 $\alpha$ are attenuated by administration of minocycline in A $\beta_{\mid-42}$ infused rats and Tg2576 mice. (a and b) The fixed brains of $A \beta_{1-42}$ infused rats administered vehicle or minocycline $(n=4)$, (c and d) the fixed brains of Tg2576 mice administered vehicle or minocycline $(n=4)$ in $10 \%$ neutral-buffered formalin for $48 \mathrm{~h}$ were dehydrated and embedded in paraffin. The fluorescent immunohistochemistry was performed in CAI (a and $c$ ) and CA3 ( $b$ and $d$ ) with p-elF2 $\alpha$ antibody overnight and visualized using Cy3-conjugated secondary antibody (Jackson, West Grove, PA). DAPI (I $\mu$ M) counterstaining was performed. Images were collected using the LSM 510 program on a Zeiss confocal microscope. Scale bar indicates I $00 \mu \mathrm{m}$; in inset, also $100 \mu \mathrm{m}$. The results are representative of four separate experiments performed with different samples, respectively.

compared to control rats (Figure $4 \mathrm{a}$ and $\mathrm{b}$ ), whereas there was no noticeable difference in the immunoreactivities of eIF2 $\alpha$ between two animal groups (data not shown). Minocycline administration $(45 \mathrm{mg} / \mathrm{kg} /$ day $)$ for 3 weeks i.p. after $\mathrm{A} \beta_{1-42}(600 \mathrm{pmol} /$ day) having been infused into rat lateral ventricles continuously for a week significantly reduced the p-eIF2 $\alpha$ immunoreactivities (Figure $4 a$ and b).
We confirmed that there was no noticeable difference between PBS- and minocycline-treated sham-operated animals (Figure $4 \mathrm{a}$ and $\mathrm{b}$ ).

Additionally, we examined the effects of minocycline on the phosphorylation status of e-IF $2 \alpha$ in Tg2576 mice. Minocycline $(10 \mathrm{mg} / \mathrm{kg} / \mathrm{day})$ or PBS was administered to Tg2576 mice or wt mice i.p. from 3 months after birth, 5 
age-matched control brain
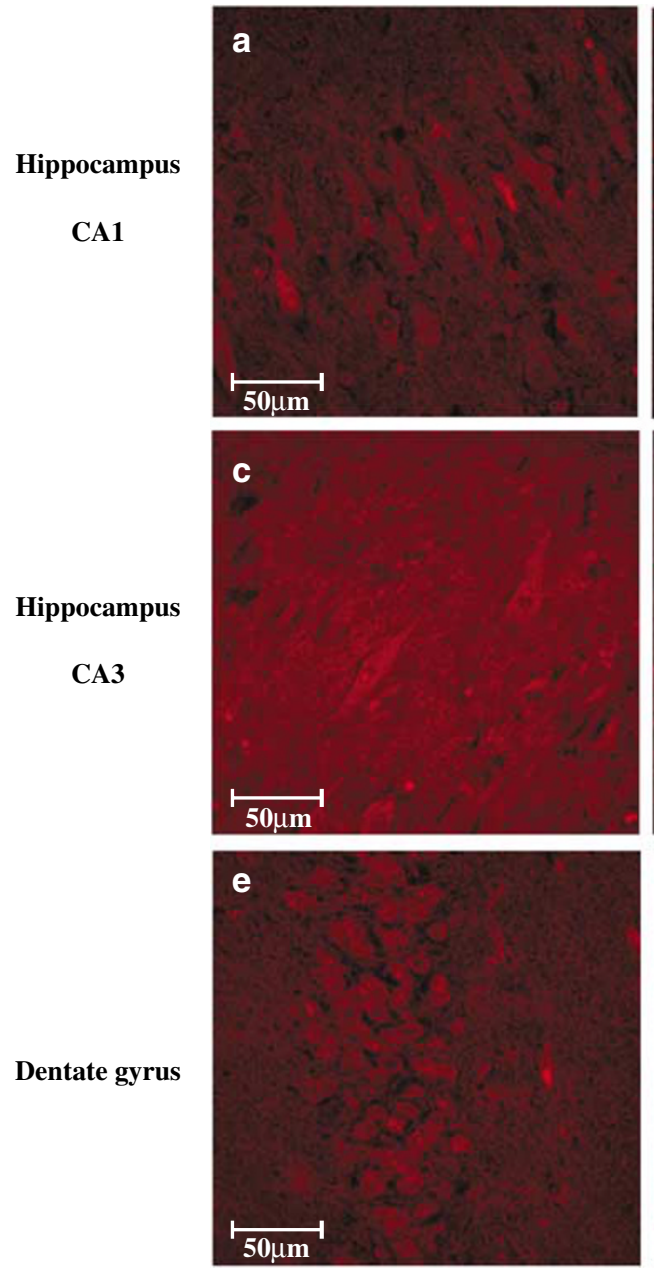

AD brain
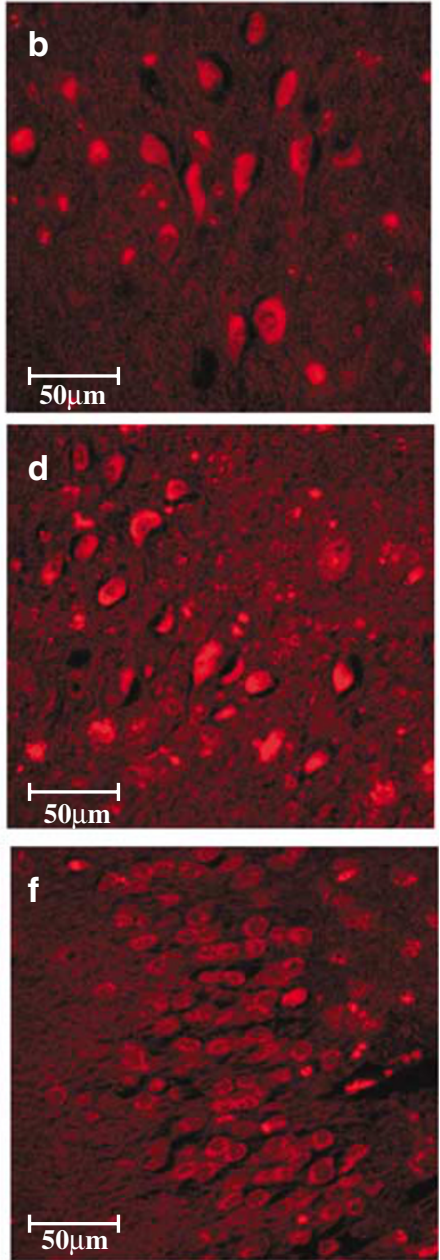

Figure 5 p-elF $2 \alpha$ immunoreactivities are elevated in CAI, CA3, and dentate gyrus from human AD brains. The fixed brains of age-matched control or AD brains $(n=3)$ in 10\% neutral-buffered formalin for $48 \mathrm{~h}$ were dehydrated and embedded in paraffin. The fluorescent immunohistochemistry was performed in CAI ( $a$ and b), CA3 (c and d) and dentate gyrus (e and f) with p-elF2 $\alpha$ antibody overnight and visualized using Cy3-conjugated secondary antibody (Jackson, West Grove, PA). Scale bar indicates $50 \mu \mathrm{m}$. The results are representative of three separate experiments performed with different samples, respectively.

days per week for 9 months. Prominent staining of p-eIF $2 \alpha$ in these 12 month-old Tg2576 mice appeared in CA1 and CA3, compared to the same-aged wt mice (Figure $4 \mathrm{c}$ and d). Minocycline administered Tg2576 mice showed significantly low level of the p-eIF2 $\alpha$ immunoreactivities in the same regions (Figure $4 \mathrm{c}$ and $\mathrm{d}$ ). We confirmed that the p-eIF2 $\alpha$ in Tg2576 mice was significantly upregulated compared to age-matched wt mice (Figure $4 \mathrm{c}$ and d), whereas no significant difference in eIF2 $\alpha$ level was observed between Tg2576 and wt mice (data not shown).

\section{p-eIF $2 \alpha$ Immunoreactivities were Elevated in CA1, CA3, and Dentate Gyrus from Human AD Brains}

To seek after a physiological significance for the increased p-eIF2 $\alpha$ levels in the brains of $A \beta_{1-42}$ infused rats or Tg2576 mice, we examined the changes in p-eIF2 $\alpha$ in human AD brains compared to age-matched control brains using immunohistochemical analysis. AD brain sections revealed stronger immunoreactivity for p-eIF $2 \alpha$ in CA1 (Figure $5 b$ ),
CA3, (Figure 5d) and dentate gyrus (Figure 5f), compared to the same regions of age-matched control brains (Figure 5a, c and e), consistent with a previous finding (Chang et al, 2002a).

\section{DISCUSSION}

\section{Minocycline: Generalities and Therapeutic, Experimental Doses}

Minocycline, a broad-spectrum, semi-synthetic antibiotic belonging to the tetracycline family is being used for acne vulgaris, some sexually transmitted diseases and rheumatoid arthritis (Blum et al, 2004; Good and Hussey, 2003). The therapeutic doses of minocycline, approved by the FDA, for the diseases described above are 100-200 mg/day (Blum et al, 2004). In animals, minocycline is lethal at very high doses $\left(\mathrm{LD}_{50}: 3600 \mathrm{mg} / \mathrm{kg}\right.$; Blum et al, 2004; Smith et al, 2003). In humans, long-term treatment with minocycline up to $200 \mathrm{mg} /$ day is generally safe and well tolerated as 
demonstrated by tolerability tests and clinical trials in rheumatoid arthritis, acne vulgaris, and $\mathrm{HD}$ (Blum et al, 2004; Bonelli et al, 2003).

In in vitro experiments recently reported on the neuroprotective effects exerted by minocycline, $2-100 \mu \mathrm{M}$ concentrations of minocycline were used in various neuronal cell experimental models (Wang et al, 2003, 2004; Zhu et al, 2002). In the present study, we used $10 \mu \mathrm{M}$ concentration of minocycline in in vitro experiments based on dose-dependent study (Figure 1b) and the study by others (Suk, 2004; Zhu et al, 2002). In in vivo study, a large range of doses were used for testing the effects of minocycline in various animal models, that is $5 \mathrm{mg} / \mathrm{kg} / \mathrm{day}$ i.p. in R6/2 mice, transgenic mice for HD (Chen et al, 2000), $10-50 \mathrm{mg} / \mathrm{kg} /$ day i.p. in $\mathrm{SOD}^{\mathrm{G} 93 \mathrm{~A}}$ mutant mice (Van Den et al, 2002; Zhu et al, 2002), $10 \mathrm{mg} / \mathrm{kg} /$ day subcutaneous release pellet in Ts65Dn mice, animal model for Down's syndrome (Hunter et al, 2004b), $45 \mathrm{mg} / \mathrm{kg} /$ day i.p. in C57BL/6-p75-SAP mice (Hunter et al, 2004a) and 60, 90, $90 \mathrm{mg} / \mathrm{kg} /$ day p.o. in MPTP PD animal model (Du et al, 2001). We administrated $45 \mathrm{mg} / \mathrm{kg} /$ day dose of minocycline for 3 weeks into $\mathrm{A} \beta_{1-42}$ infused rats and tested the effects of the drug treatment compared with PBS-administered groups.

\section{Minocycline and Neurodegenerative Diseases}

In recent years, minocycline has been reported to have neuroprotective effects in various experimental neurodegenerative disease models such as cerebral ischemia (Yrjanheikki et al, 1999), traumatic brain injury (Sanchez Mejia et al, 2001), ALS (Zhu et al, 2002), PD (Wu et al, 2002), and HD (Chen et al, 2000; Wang et al, 2003). At present, a few number of studies are focused on the therapeutical potential of minocycline in $\mathrm{AD}$ (Hunter et al, 2004a; Seabrook et al, 2006), where it suppressed microglial production of IL-1beta, IL-6, TNF, and NGF in in vitro as well as APP transgenic mice (Seabrook et al, 2006). In addition, minocycline attenuated cholinergic cell loss, glial activation, and transcription of downstream pro-inflammatory mediators and mitigated the cognitive impairment, induced by mu p75-saporin, a novel immunotoxin that mimics the selective loss of basal forebrain cholinergic neurons and induces cognitive impairment in mice. These reports showed that minocycline exerts neuroprotective effects based on its anti-inflammatory actions in $\mathrm{AD}$ experimental animal models.

We have now demonstrated that minocycline attenuates the increases in phosphorylation of eIF $2 \alpha$, thereby reducing neuronal cell death and improving cognitive impairment in in vitro and in vivo $\mathrm{AD}$ models.

\section{Possible Relationship between Phosphorylation of eIF $2 \alpha$ and Impaired Synaptic Plasticity in AD}

Whereas some previous studies support the hypothesis that neuronal cell death induced by $\mathrm{A} \beta$ deposited in neuritic plaque is the causative factor for $\mathrm{AD}$, another possibility may be that synaptic failure and impairment of cognitive function precede neuronal degeneration, especially in the early phase of AD (Selkoe, 2002).
A common strategy in the cellular response to stress signals is to shut down protein synthesis (Taylor et al, 2005). Translation of eukaryotic mRNAs is regulated primarily at the level of initiation (Costa-Mattioli et al, 2005). Binding of the initiator tRNA, Met-tRNAi ${ }^{\text {Met }}$, to the $40 \mathrm{~S}$ subunit is facilitated by the eIF $2 \alpha$ which forms a ternary complex with GTP and Met-tRNAi ${ }^{\text {Met }}$. Although the phosphorylation of eIF $2 \alpha$ can inhibit general translation (Sonenberg and Dever, 2003), it stimulates the mRNA translation of the transcriptional modulator ATF4 (Harding et al, 2000) that inhibits CREB activity, thereby downregulating its immediate early genes (BDNF, c-fos, EGR-1) (Costa-Mattioli et al, 2005).

ER stress has recently been believed to be involved in the pathogenesis of neurodegenerative diseases including $\mathrm{AD}$ (DeGracia and Montie, 2004; Katayama et al, 2004; Lindholm et al, 2006; Smith et al, 2005). e-IF2 $\alpha$ is known to be phosphorylated by some kinases including PKR, PERK, HRI, and GCN2 under various stresses such as ER stress (Taylor et al, 2005).

A recent paper reported that the inhibition of phosphorylation of eIF- $2 \alpha$ by knocking out GCN2 enhanced longterm potentiation (Costa-Mattioli et al, 2005).

The interesting finding of our study is that minocycline attenuates increased phosphorylation of eIF- $2 \alpha$ in $\mathrm{A} \beta_{1-42^{-}}$ treated or APP-CTs-transfected differentiated PC 12 cells and in the CA1 and CA3 of two animal models of $\mathrm{AD} ; \mathrm{A} \beta_{1-42}$ infused rats and Tg2576 mice. $\mathrm{A} \beta$ has been reported to phosphorylate eIF- $2 \alpha$ via PKR activation in neuronal cells (Chang et al, 2002b; Suen et al, 2003). We found that minocycline reduced PKR phosphorylation at threonine 446 and 451 induced by $\mathrm{A} \beta_{1-42}$ treatment (Figure $1 \mathrm{~d}$ ). Previous reports demonstrated that activation of PKR and p-eIF2 $\alpha$ are observed in the degenerating neurons of $\mathrm{AD}$ brains (Chang et al, 2002a) and in cultured neuronal cells treated with $\mathrm{A} \beta$ (Chang et al, 2002b). PKR is known to play a crucial role in mediating $\mathrm{A} \beta$-induced neuronal death because primary cortical neurons from PKR KO mice and neuroblastoma SH-SY5Y cells stably transfected with dominant-negative PKR mutants are less susceptible to $\mathrm{A} \beta$ toxicity (Chang et al, 2002b). Activated PKR can phosphorylate eIF2 $\alpha$ at serine 51 (Suen et al, 2003). Phosphorylation of eIF $2 \alpha$ that could increase owing to many factors by $\mathrm{A} \beta_{1-42}$, APP-CTs expression or Swedish APP transgenes in Tg2576 mice, might contribute to impairment in synaptic plasticity and cognitive function before causing neurodegeneration.

In addition, our Morris Water Maze and passive avoidance test results show that minocycline improves learning and memory impairment in $\mathrm{A} \beta_{1-42}$ infused animal model. Taking these in vitro and in vivo results together, our results suggest that minocycline has a therapeutic potential for $\mathrm{AD}$.

\section{Minocycline: Proposed Modes of Action}

Almost all the beneficial effects of minocycline are demonstrated to be related to an inhibitory activity on inflammation and/or apoptotic cell death, both phenomena being closely associated with neurodegeneration (Blum et al, 2004). Minocycline reduces the proliferation/activation of resting microglial cells as evidenced by CD11b/ 
OX42, MAC-2 or isolectine-B4 staining (Dommergues et al, $2003-45 \mathrm{mg} / \mathrm{kg}$ i.p.; He et al, $2001-45 \mathrm{mg} / \mathrm{kg}$ i.p.). Several reports showed that minocycline reduces the expression of inducible nitric oxide synthase and subsequent nitric oxide production as well as caspase-1 activity/expression and thereby prevents the formation of interleukin $1 \beta$ (Chen et al, $2000-5 \mathrm{mg} / \mathrm{kg} /$ day i.p.; Du et al, $2001-60-90 \mathrm{mg} / \mathrm{kg}$ p.o.). Additionally, minocycline can modulate neuronal cell death through an interaction with the apoptotic machinery (Blum et al, 2004). It acts at the mitochondria to rescue the collapse of transmembrane potential and the alteration of permeability transition, which are responsible for the cytosolic release of apoptogenic factors such as cytochrome c, AIF or Smac/Diablo mediating caspase-dependent and independent cell death (Matsuki et al, 2003; Wang et al, $2003-5 \mathrm{mg} / \mathrm{kg}$ i.p.; Zhu et al, 2002-22.5-45 mg/kg i.p.).

In this study, we report a new aspect of minocycline in in vitro and in vivo $\mathrm{AD}$ models. Minocycline attenuates the increases in the phosphorylation of PKR, eIF- $2 \alpha$ and caspase 12 activation induced by $\mathrm{A} \beta_{1-42}$ treatment in NGF-differentiated PC 12 cells, as well as in $\mathrm{A} \beta_{1-42}$ infused rats and Tg2576 mice. The eIF $2 \alpha$ kinases are activated by various stresses to halt translation by phosphorylating, and thereby inhibiting eIF2 $\alpha$. PKR, which is known to be activated by $\mathrm{A} \beta$, is activated in response to ER stress. The ER is an essential intracellular organelle involved in intracellular calcium homeostasis, in folding and processing of proteins, and in cell death activation (Baumann and $\mathrm{Walz}, 2001)$. Changes in ER $\mathrm{Ca}^{2+}$ homeostasis and ROS induce the accumulation of unfolded proteins and activate the ER-stress-induced apoptosis pathway (Kaufman, 1999; Pashen, 2001).

It was previously shown that caspase-12 knockout mice are resistant to ER stress and to death caused by $\mathrm{A} \beta$ protein (Nakagawa et al, 2000), strongly supporting that ER stress is involved in the neuronal death that occurs in $\mathrm{AD}$. In vitro studies have suggested that $\mathrm{ER} \mathrm{Ca}^{2+}$ dyshomeostasis and oxidative stress are synergistically related. Although ER function is sensitive to the presence of oxidants (Dreher et al, 1995; Hayashi et al, 2005; Racay et al, 1995; Viner et al, 1996), ROS can also be produced intracellularly from the stress-regulated release of calcium from the ER.

Although further research is needed, we speculate that minocycline attenuates ER stress by $\mathrm{A} \beta$, thereby reducing phosphorylation of eIF- $2 \alpha$ shown in cell cultured models as well as $\mathrm{A} \beta_{1-42}$ infused rats or Tg2576 mice.

\section{ACKNOWLEDGEMENTS}

This work was supported by a National Creative Research Initiative Grant (2006-2009) from MOST, in part by the BK21 Human Life Sciences program and by a grant from Seoul National University Bundang Hospital Research Fund.

\section{REFERENCES}

Baumann O, Walz B (2001). Endoplasmic reticulum of animal cells and its organization into structural and functional domains. Int Rev Cytol 205: 149-214.

Blum D, Chtarto A, Tenenbaum L, Brotchi J, Levivier M (2004). Clinical potential of minocycline for neurodegenerative disorders. Neurobiol Disease 17: 359-366.
Bonelli RM, Heuberger C, Reisecker F (2003). Minocycline for Huntington's disease: an open label study. Neurology 60: 883-884.

Chang RC, Wong AK, Ng HK, Hugon J (2002a). Phosphorylation of eukaryotic initiation factor-2 alpha (eIF2alpha) is associated with neuronal degeneration in Alzheimer's disease. Neuroreport 13: 2429-2432.

Chang RC, Suen KC, Ma CH, Elyman W, Ng HK, Hugon J (2002b). Involvement of double-stranded RNA-dependent protein kinase and phosphorylation of eukaryotic initiation factor-2alpha in neuronal degeneration. J Neurochem 83: $1215-1225$.

Chen A, Muzzio IA, Malleret G, Bartsch D, Verbitsky M, Pavlidis P et al (2003). Inducible enhancement of memory storage and synaptic plasticity in transgenic mice expressing an inhibitor of ATF4 (CREB-2) and C/EBP proteins. Neuron 39: 655-669.

Chen M, Ona VO, Li M, Ferrante RJ, Fink KB, Zhu S et al (2000). Minocycline inhibits caspase- 1 and caspase- 3 expression and delays mortality in a transgenic mouse model of Huntington disease. Nat Med 6: 797-801.

Cho KO, La HO, Cho YJ, Sung KW, Kim SW (2006). Minocycline attenuates white matter damage in a rat model of chronic cerebral hypoperfusion. J Neurosci Res 83: 285-291.

Cleary JP, Walsh DM, Hofmeister JJ, Shankar GM, Kuskowski MA, Selkoe DJ et al (2005). Natural oligomers of the amyloid-beta protein specifically disrupt cognitive function. Nat Neurosci 8: 79-84.

Costa-Mattioli M, Gobert D, Harding H, Herdy B, Azzi M, Bruno M et al (2005). Translational control of hippocampal synaptic plasticity and memory by the eIF2alpha kinase GCN2. Nature 436: 1166-1173.

DeGracia DJ, Montie HL (2004). Cerebral ischemia and the unfolded protein response. J Neurochem 91: 1-8.

Dommergues MA, Plaisant F, Vemey C, Gressens P (2003). Early microglial activation following neonatal excitotoxic brain damage in mice: a potential target for neuroprotection. Neuroscience 121: 619-628.

Dreher D, Jornot L, Junod AF (1995). Effects of hypoxantinexantine oxidase on $\mathrm{Ca}^{2+}$ stores and protein synthesis in human endothelial cells. Circ Res 76: 388-395.

Du Y, Ma Z, Lin S, Dodel RC, Gao F, Bales KR et al (2001). Minocycline prevents nigrostriatal dopaminergic neurodegeneration in the MPTP model of Parkinson's disease. Proc Natl Acad Sci 98: 14669-14674.

Good ML, Hussey DL (2003). Minocycline stain devil? $\mathrm{Br} J$ Dermatol 149: 237-239.

Harding HP, Novoa I, Zhang Y, Zeng H, Wek R, Schapira M et al (2000). Regulated translation initiation controls stress-induced gene expression in mammalian cells. Mol Cell 6: 1099-1108.

Harding HP, Zhang Y, Ron D (1999). Protein translation and folding are coupled by an endoplasmic-reticulum-resident kinase. Nature 397: 271-274.

Hayashi T, Saito A, Okuno S, Ferrand-Drake M, Dodd RL, Chan PH (2005). Damage to the endoplasmic reticulum and activation of apoptotic machinery by oxidative stress in ischemic neurons. J Cereb Blood Flow Metab 25: 41-53.

He Y, Appel S, Le W (2001). Minocycline inhibits microglial activation and protects nigral cells after 6-hydroxydopamine injection into mouse striatum. Brain Res 909: 187-193.

Heo K, Cho YJ, Cho KJ, Kim HW, Kim HJ, Shin HY et al (2006). Minocycline inhibits caspase-dependent and -independent cell death pathways and is neuroprotective against hippocampal damage after treatment with kainic acid in mice. Neurosci Lett 398: 195-200.

Hsiao K, Chapman P, Nilsen S, Eckman C, Harigaya Y, Younkin S et al (1996). Correlative memory deficits, Abeta elevation, and amyloid plaques in transgenic mice. Science 274: 99-102. 
Hunter C, Bachman C, Granholm AC (2004b). Minocycline prevents cholinergic loss in a mouse model of Down's syndrome. Ann Neurol 56: 675-688.

Hunter CL, Quintero EM, Gilstrap L, Bhat NR, Grandhelm AC (2004a). Minocycline protects basal forebrain cholinergic neurons from mu p75-saporin immunotoxic lesioning. Eur J Neurosci 19: 3305-3316.

Kandel ER (2001). The molecular biology of memory storage: a dialogue between genes and synapses. Science 294: 1030-1038.

Katayama T, Imaizumi K, Manabe T, Hitomi J, Kudo T, Tohyama $M$ (2004). Induction of neuronal death by ER stress in Alzheimer's disease. J Chem Neuroanat 28: 67-78.

Kaufman RJ (1999). Stress signaling from the lumen of the endoplasmic reticulum: coordination of gene transcriptional and translational controls. Genes Dev 13: 1211-1233.

Lindholm D, Wootz H, Korhonen L (2006). ER stress and neurodegenerative diseases. Cell Death Differ 13: 385-392.

Matsuki S, Iuchi Y, Ikeda Y, Sasagawa I, Tomita Y, Fujii J (2003). Suppression of cytochrome $c$ release and apoptosis in testes with heat stress by minocycline. Biochem Biophys Res Commun 312: 843-849.

Nakagawa T, Zhu H, Morishima N, Li E, Xu J, Yankner BA et al (2000). Caspase-12 mediates endoplasmic-reticulum-specific apoptosis and cytotoxicity by amyloid-beta. Nature 403: 98-103.

Nitta A, Fukuta T, Hasegawa T, Nabeshima T (1997). Continuous infusion of beta-amyloid protein into the rat cerebral ventricle induces learning impairment and neuronal and morphological degeneration. Jpn J Pharmacol 73: 51-57.

Pashen W (2001). Dependence of vital cell function on endoplasmic reticulum calcium levels: implications for the mechanisms underlying neuronal cell injury in different pathological states. Cell Calcium 29: 1-11.

Popovic N, Schubart A, Goetz BD, Zhang SC, Linington C, Duncan ID (2002). Inhibition of autoimmune encephalomyelitis by a tetracycline. Ann Neurol 51: 215-223.

Racay P, Kaplan P, Lehotsky J, Mezesova V (1995). Rabbit brain endoplasmic reticulum membranes as target for free radicals. Changes in $\mathrm{Ca}^{2+}$-transport and protection by stobadine. Biochem Mol Biol Int 36: 569-577.

Sanchez Mejia RO, Ona VO, Li M, Friendlander RM (2001). Minocycline reduces traumatic brain injury-mediated caspase-1 activation, tissue damage, and neurological dysfunction. Neurosurgery 48: 1393-1399.

Schuster D, Rajendran A, Hui SW, Nicotera T, Srikrishnan T, Kruzel ML (2005). Protective effect of colostrinin on neuroblastoma cell survival is due to reduced aggregation of betaamyloid. Neuropeptides 39: 419-426.

Seabrook TJ, Jiang L, Maier M, Lemere C (2006). Minocycline affects microglia activation, Abeta deposition, and behavior in APP-tg mice. Glia 53: 776-782.

Selkoe DJ (2001). Alzheimer's disease: genes, proteins, and therapy. Physiol Rev 81: 741-766.

Selkoe DJ (2002). Alzheimer's disease is a synaptic failure. Science 298: 789-791.
Smith DL, Woodman B, Mahal A, Sathasivam K, Ghazi-Noori S, Lowden PA et al (2003). Minocycline and doxycycline are not beneficial in a model of Huntington's disease. Ann Neurol 54: 186-196.

Smith WW, Jiang H, Pei J, Tanaka Y, Morita Y, Sawa A et al (2005). Endoplasmic reticulum stress and mitochondrial cell death pathways mediate A53T mutant alpha-synuclein-induced toxicity. Hum Mol Genet 14: 3801-3811.

Sonenberg N, Dever TE (2003). Eukaryotic translation initiation factors and regulators. Curr Opin Struct Biol 13: 56-63.

Suen K, Yu M, So F, Chang RC, Hugon J (2003). Upstream signaling pathways leading to the activation of double-stranded RNA-dependent serine/threonine protein kinase in beta-amyloid peptide neurotoxicity. J Biol Chem 278: 49819-49827.

Suk K (2004). Minocycline suppresses hypoxic activation of rodent microglia in culture. Neurosci Lett 366: 167-171.

Taylor SS, Haste NM, Ghosh G (2005). PKR and eIF2alpha: integration of kinase dimerization, activation, and substrate docking. Cell 122: 823-825.

Van Den BL, Tiken P, Lemmens G, Robberecht W (2002). Minocycline delays disease onset and mortality in a transgenic model of ALS. NeuroReport 13: 1067-1070.

Viner RI, Huhmer AF, Bigelow DJ, Schoneich C (1996). The oxidative inactivation of sarcoplasmic reticulum $\mathrm{Ca}(2+)$-ATPase by peroxynitrite. Free Radic Res 24: 243-259.

Walsh DM, Klyubin I, Fadeeva JV, Cullen WK, Anwyl R, Wolfe MS et al (2002). Naturally secreted oligomers of amyloid beta protein potently inhibit hippocampal long-term potentiation in vivo. Nature 416: 535-539.

Wang J, Wei Q, Wang CY, Hill WD, Hess DC, Dong Z (2004). Minocycline upregulates Bcl-2 and protects against cell death in mitochondria. J Biol Chem 279: 19948-219854.

Wang X, Zhu S, Drozda M, Zhang W, Stavrovskaya IG, Cattaneo E et al (2003). Minocycline inhibits caspase-independent and -dependent mitochondrial cell death pathways in models of Huntington's disease. Proc Natl Acad Sci USA 100: 10483-10487.

Wu DC, Jackson-Lewis V, Vila M, Tieu K, Teismann P, Vadseth C et al (2002). Blockade of microglial activation is neuroprotective in the 1-methyl-4-phenyl-1,2,3,6-tetrahydropyridine mouse model of Parkinson disease. J Neurosci 22: 1763-1771.

Yankner BA (1996). Mechanisms of neuronal degeneration in Alzheimer's disease. Neuron 16: 921-932.

Yong VW, Wells J, Giuliani F, Casha S, Power C, Metz LM (2004). The promise of minocycline in neurology. Lancet Neurol 3: 744-751.

Yrjanheikki J, Tikka T, Keinanen R, Goldsteins G, Chan PH, Koistinaho J (1999). A tetracycline derivative, minocycline, reduces inflammation and protects against focal cerebral ischemia with a wide therapeutic window. Proc Natl Acad Sci USA 96: 13496-13500.

Zhu S, Stavrovskaya IG, Drozda M, Kim BY, Ona V, Li M et al (2002). Minocycline inhibits cytochrome c release and delays progression of amyotrophic lateral sclerosis in mice. Nature 417: 74-78. 